\title{
KESADARAN HUKUM UMAT ISLAM DI DAERAH ISTIMEWA YOGYAKARTA UNTUK MEMBAYAR ZAKAT MELALUI AMIL ZAKAT*
}

\author{
Yulkarnain Harahab** \\ Bagian Hukum Islam Fakultas Hukum Universitas Gadjah Mada \\ Jalan Sosio Yustisia Nomor 1, Bulaksumur, Sleman, D.I. Yogyakarta 55281
}

\begin{abstract}
Based on Islamic law, paying of zakah by moslems should be done via amil zakah. According to Act Number 23 Year 2011 about Zakah Management, the amil zakah is National Amil Zakah Board (Badan Amil Zakat Nasional/BAZNAS) and Amil Zakah Institution (Lembaga Amil Zakat/LAZ). This research shows that, first, legal consciousness of Moslems in Yogyakarta Special Regency to pay zakah via Amil Zakah is less relatively, second, a factor that influence less of the legal consciousness is less understanding of Zakah Management Act, third, Zakah Management Act is not effective to increase paying zakah via amil zakah yet.
\end{abstract}

Keywords: legal consciousness, paying of zakah, amil zakah.

\section{Intisari}

Berdasarkan ketentuan Hukum Islam, pembayaran zakat oleh umat Islam seharusnya dilakukan melalui amil zakat. Amil zakat dimaksud menurut Undang-undang Nomor 23 Tahun 2011 tentang Pengelolaan Zakat adalah Badan Amil Zakat Nasional (BAZNAS) dan Lembaga Amil Zakat (LAZ). Hasil penelitian ini menunjukkan bahwa, pertama, kesadaran hukum umat Islam di Daerah Istimewa Yogyakarta untuk membayar zakat melalui amil zakat masih relatif rendah, kedua, faktor yang mempengaruhi rendahnya kesadaran hukum tersebut adalah kurangnya pemahaman umat Islam terhadap ketentuan Undang-undang Pengelolaan Zakat, ketiga, Undang-undang Pengelolaan Zakat belum efektif dalam meningkatkan pengumpulan zakat melalui amil zakat.

Kata Kunci: kesadaran hukum, pembayaran zakat, amil zakat.

\section{Pokok Muatan}

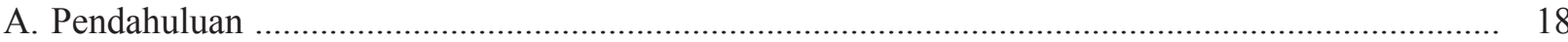

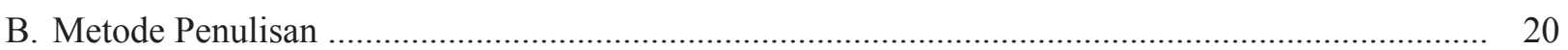

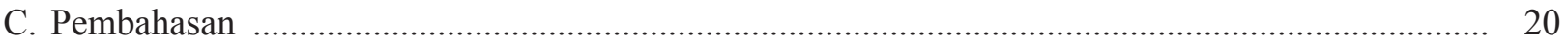

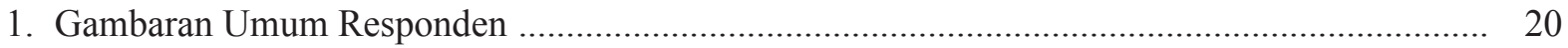

2. Kesadaran Hukum Umat Islam di Daerah Istimewa Yogyakarta untuk Membayar Zakat melalui Badan Amil Zakat Nasional (BAZNAS) atau Lembaga Amil Zakat (LAZ) .................. 22

3. Faktor yang Mempengaruhi Kesadaran Hukum Umat Islam di Daerah Istimewa Yogyakarta untuk Membayar Zakat Melalui Badan Amil Zakat Nasional (BAZNAS) atau Lembaga Amil Zakat (LAZ)

4. Efektivitas Ketentuan Undang-Undang Pengelolaan Zakat Menyangkut Pengumpulan Zakat melalui Badan Amil Zakat Nasional (BAZNAS) atau Lembaga Amil Zakat (LAZ) ................. 30

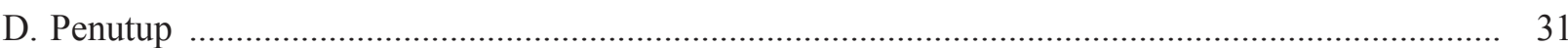

\footnotetext{
Hasil Penelitian didanai Unit Penelitian dan Pengabdian kepada Masyarakat Fakultas Hukum UGM, 2014.

** Alamat korespondensi: yulkarnain.harahap@mail.ugm.ac.id
} 


\section{A. Pendahuluan}

Zakat merupakan salah satu kewajiban umat Islam yang harus ditunaikan, disamping kewajiban-kewajiban yang lain. Dalam Al-Qur'an, kewajiban zakat ini sering dirangkaikan dengan kewajiban sholat (ada 27 ayat yang menyatakan hal demikian). ${ }^{1}$ Hal itu menunjukkan bahwa tidak sempurnalah Islam seseorang jika hanya rajin shalat namun melalaikan zakat. Dengan kata lain tidaklah cukup seseorang hanya memiliki kesalehan pribadi, namun tidak memiliki kesalehan sosial.

Salah satu ayat Al-Qur'an yang menyatakan kewajiban zakat bagi setiap umat Islam adalah Surat Al-Baqarah ayat 43, yang artinya "Dirikanlah shalat, tunaikanlah zakat, dan rukuklah bersamasama orang yang rukuk". Zakat juga merupakan salah satu rukun Islam, sebagaimana disebutkan dalam hadits yang artinya "Islam didirikan atas lima sendi, yaitu bersaksi bahwa tiada Tuhan selain Allah dan Muhammad adalah rasul Allah, mendirikan shalat, menunaikan zakat, mengerjakan haji dan berpuasa di bulan Ramadhan" (HR Muslim dari Ibnu Umar). Di samping itu, di antara para mujtahid juga terdapat ijma' (konsensus) yang menyatakan bahwa orang Islam yang mengingkari kewajiban zakat berarti telah kafir.

Berbeda dengan ibadah yang lain, zakat memiliki dua dimensi, yaitu hablum minallah dan hablum minannas. Artinya, bahwa dengan menunaikan zakat, seorang muslim disamping telah mendekatkan diri kepada Allah dengan memenuhi kewajiban-Nya, juga telah membantu sesamanya yang membutuhkan. Dengan berzakat, disatu sisi akan menghilangkan sifat egois (mementingkan diri sendiri) dan sifat kikir, di sisi lain akan meratakan kesejahteraan sehingga akan mengurangi jurang pemisah yang terlalu dalam antara si kaya dan si miskin.

Sesuai ketentuan Al-Qur'an dan praktek yang dijalankan Rasulullah, pembayaran zakat tidaklah dilakukan secara langsung dari muzakki (orang yang berkewajiban menunaikan zakat) kepada mustahik (orang yang berhak menerima zakat), melainkan melalui pihak ketiga yang disebut amil (pengelola zakat). Dengan demikian mekanisme pembayaran zakat dapat digambarkan sebagai berikut: ${ }^{2}$

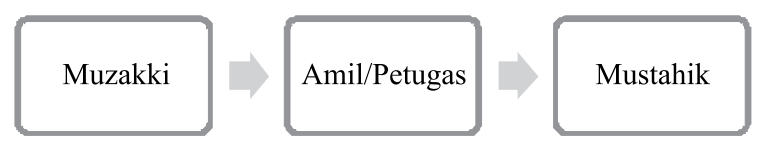

Dengan adanya lembaga amil (petugas/pengelola zakat) dalam penunaian zakat, menunjukkan bahwa kewajiban zakat tidaklah sekedar bersifat karitatif, melainkan bersifat otoritatif. ${ }^{3}$ Salah satu ayat Al-Qur'an yang menunjukkan bahwa pembayaran zakat seharusnya dilakukan melalui amil adalah Surat At-Taubah ayat 103, yang artinya "Ambillah zakat dari sebagian harta mereka, dengan zakat itu kamu membersihkan dan mensucikan mereka, dan berdoalah untuk mereka. Sesungguhnya doa kamu itu (menjadi) ketenteraman jiwa bagi mereka. Dan Allah Maha Mendengar lagi Maha Mengetahui”. Dalam ayat tersebut terdapat kata "ambillah zakat [....]", hal itu berarti ada pihak yang diperintahkan untuk mengambil zakat, dan ada pihak yang diambil zakatnya. Pihak yang diperintahkan untuk mengambil zakat tersebut tidak lain adalah amil zakat. Hal ini juga diperkuat dalam Al-Qur'an Surat At-Taubah ayat 60 yang menyebutkan bahwa salah satu pihak yang berhak menerima zakat adalah amil. Dengan demikian, keberadaan amil zakat mendapat legitimasi yang kuat dalam Al-Qur'an.

Banyak nilai positif atau manfaat yang diperoleh jika pembayaran zakat dilakukan melalui amil. Beberapa manfaat tersebut adalah: ${ }^{4}$ (a) kepastian muzakki untuk membayar zakat, sehingga hak-hak fakir miskin juga lebih terjamin; dan (b) menghilangkan rasa rendah diri dari mustahik. Dengan pembayaran zakat melalui amil dan selanjutnya amil menyalurkannya kepada yang

Monzer Kahf, “Zakah”, http://www.monzer.kahf.com, diakses 25 Januari 2012. 
berhak (mustahik), maka hal ini akan menghilangkan kesan mustahik seperti orang yang meminta-minta kepada muzakki; (c) Terwujudnya efisiensi dan efektivitas dalam pengumpulan dan penyaluran zakat; (d) Mewujudkan syiar Islam.

Sebaliknya, jika zakat diserahkan langsung dari muzakki kepada mustahik, meskipun secara hukum syariah adalah sah, akan tetapi di samping akan terabaikannya hal-hal tersebut di atas, juga hikmah dan fungsi zakat, terutama yang berkaitan dengan kesejahteraan umat, akan sulit diwujudkan. ${ }^{5}$

Berdasarkan ketentuan Undang-undang Nomor 23 Tahun 2011 tentang Pengelolaan Zakat, ada dua macam organisasi pengelola zakat yang bertindak sebagai amil, yaitu Badan Amil Zakat Nasional (BAZNAS) dan Lembaga Amil Zakat (LAZ). BAZNAS merupakan organisasi pengelola zakat yang dibentuk oleh pemerintah yang terdiri dari unsur masyarakat dan pemerintah, sedangkan LAZ adalah institusi pengelolaan zakat yang sepenuhnya dibentuk atas prakarsa masyarakat dan oleh masyarakat yang bergerak di bidang dakwah, pendidikan, sosial, dan kemaslahatan umat Islam. ${ }^{6}$

Sejak diberlakukannya Undang-undang Pengelolaan Zakat tersebut, jumlah pengumpulan zakat melalui BAZNAS maupun LAZ belum seperti yang diharapkan. Berdasarkan hasil riset Badan Amil Zakat Nasional (BAZNAS) bersama dengan Fakultas Ekonomi dan Manajemen (FEM) IPB Tahun 2011 tentang Optimalisasi Potensi Zakat Nasional menunjukkan bahwa potensi zakat secara nasional per tahun dapat mencapai angka 217 triliun rupiah atau setara dengan 3,40 persen dari total PDB (Produk Domestik Bruto) Nasional. ${ }^{7}$ Namun dalam realisasinya, dana zakat yang terkumpul secara nasional dapat dikatakan masih sangat kecil dari besarnya potensi yang ada, terhitung pada tahun 2010 dana zakat yang terkumpul melalui BAZNAS hanya mencapai besaran 1,5 triliun rupiah. Hal ini tidak jauh berbeda dengan kondisi pada tahun 2013 sebagaimana dinyatakan oleh Ketua Umum Badan Amil Zakat Nasional (BAZNAS) Prof.Dr. Didin Hafidhuddin, MSc. Menurut beliau, potensi zakat secara nasional sebesar Rp 213 triliun setiap tahunnya, namun sekarang baru terealisasi sekitar Rp. 2,3 triliun atau 0,8\%. Untuk Daerah Istimewa Yogyakarta sendiri, menurut Kakanwil Kemenag DIY, Drs. H. Maskul Haji, M.Pd.I, potensi zakat di DIY dalam satu tahun sekitar Rp 5 miliar, namun saat ini baru terealisasi sekitar Rp 400 juta. $^{8}$

Berdasarkan latar belakang tersebut di atas, penulis tertarik untuk meneliti lebih lanjut tentang Kesadaran Hukum Umat Islam di Daerah Istimewa Yogyakarta untuk Membayar Zakat melalui Badan Amil Zakat Nasional (BAZNAS) atau Lembaga Amil Zakat (LAZ). Untuk memudahkan analisis dan menarik kesimpulan, penulis merumuskan permasalahan penelitian ini sebagai berikut: Pertama, bagaimanakah kesadaran hukum umat Islam di Daerah Istimewa Yogyakarta untuk membayar zakat melalui Badan Amil Zakat Nasional (BAZNAS) atau Lembaga Amil Zakat (LAZ)? Kedua, faktor apakah yang mempengaruhi kesadaran hukum umat Islam di Daerah Istimewa Yogyakarta untuk membayar zakat melalui Badan Amil Zakat Nasional (BAZNAS) atau Lembaga Amil Zakat (LAZ)? Ketiga, bagaimanakah efektivitas ketentuan Undang-undang Pengelolaan Zakat dalam meningkatkan pengumpulan zakat melalui Badan Amil Zakat Nasional (BAZNAS) atau Lembaga Amil Zakat (LAZ)?

\footnotetext{
Didin Hafidhuddin, 2004, Zakat dalam Perekonomian Modern, Gema Insani Press, Jakarta, hlm. 126.

Pasal 1 Keputusan Menteri Agama RI Nomor 581 Tahun 1999 tentang Pelaksanaan Undang-Undang Nomor 38 Tahun 1999 tentang Pengelolaan Zakat.

Hasil riset BAZNAS dan FEM IPB tentang Optimalisasi Potensi Zakat Nasional ini disampaikan dalam International Zakat Conference "Sustainable Zakat Development in The Poverty Alleviation and Improvement of Welfare of the Ummah" di Bogor, 19-21 Juli 2011. BAZNAS dan FEM IPB mengklasifikasikan potensi zakat nasional dalam tiga kelompok besar sumber pemasukan zakat dengan perincian sebagai berikut: (1) zakat rumah tangga (82,7 triliun rupiah); (2) zakat industri swasta (114,89 triliun rupiah) dan BUMN (2,4 triliun rupiah), termasuk di dalamnya adalah zakat hasil industri dan perdagangan di luar zakat karyawan dan direksi; dan (3) zakat tabungan (17 triliun rupiah), termasuk di dalamnya investasi berbentuk deposito, maupun emas dan perak.

8 Harian Kedaulatan Rakyat, 4 April 2013, hlm. 5.
} 


\section{B. Metode Penulisan}

\section{Jenis Penelitian}

Penelitian ini merupakan kombinasi antara penelitian hukum normatif dan empiris, dalam arti bahwa penelitian ini diawali dengan studi dokumen untuk mendapatkan data sekunder dan kemudian dilanjutkan dengan penelitian lapangan untuk mendapatkan data primer. Terkait dengan hal tersebut, maka bahan penelitian ini meliputi dua macam, yaitu data primer yang diperoleh dari penelitian lapangan dan data sekunder yang diperoleh dari penelitian kepustakaan.

\section{Macam Penelitian}

a. Penelitian Kepustakaan

Penelitian kepustakaan dilakukan dengan studi dokumen terhadap bahan hukum primer dan bahan hukum sekunder.

1) Bahan hukum primer adalah bahan hukum yang memiliki kekuatan mengikat, yang terdiri dari Undang-Undang Nomor 23 Tahun 2011 tentang Pengelolaan Zakat dan peraturan pelaksanaannya.

2) Bahan hukum sekunder adalah bahan hukum yang menjelaskan bahan hukum primer yang meliputi buku-buku, makalah seminar, jurnal, maupun hasilhasil penelitian yang memiliki relevansi dengan topik penelitian.

b. Penelitian Lapangan

Dalam penelitian lapangan, penulis menetapkan lokasi penelitian, subyek penelitian, dan cara pengumpulan datanya sebagai berikut:

1) Lokasi

Penelitian dilakukan di Daerah Istimewa Yogyakarta.

2) Subyek penelitian

Subyek penelitian (dalam hal

ini adalah responden) terdiri dari umat Islam sebanyak 100 (seratus) orang yang ditentukan secara non random sampling, tepatnya purposive sampling; artinya disini bahwa tidak semua umat Islam memiliki kesempatan yang sama untuk dipilih menjadi sampel penelitian, melainkan peneliti memiliki kriteria sendiri untuk menentukan siapa yang dijadikan sampel penelitian (responden). Kriteria yang ditentukan peneliti dalam penelitian ini adalah umat Islam yang berstatus muzakki (wajib zakat).

3) Pengumpulan data

Pengumpulan data dari para responden dilakukan dengan pengisian daftar pertanyaan (kuesioner) yang telah dipersiapkan sebelumnya.

\section{Analisis Data}

Data yang telah terkumpul, baik dari penelitian kepustakaan maupun penelitian lapangan selanjutnya dianalisis secara kualitatif. Dalam penelitian ini ada tiga alur kegiatan yang dilakukan, yaitu reduksi data, penyajian data, dan penarikan kesimpulan. Reduksi data meliputi proses pemilihan, pemusatan perhatian, penyederhanaan, pengabstrakan dan transformasi data mentah yang muncul dari catatan-catatan tertulis di lapangan maupun hasil wawancara yang ada. Data yang sudah direduksi sesuai dengan pokok masalah dan dibantu dengan teori-teori selanjutnya direkonstruksi dengan pendekatan kualitatif ke dalam uraian diskripsi yang utuh dan akhirnya diambil kesimpulan.

\section{Pembahasan}

\section{Gambaran Umum Responden}

Responden dalam penelitian ini berjumlah seratus orang yang dipilih dengan metode purposive sampling. Mereka adalah para muzakki (wajib zakat) yang tersebar di wilayah Kabupaten Sleman, Kabupaten Kulon Progo, Kabupaten Bantul, Kabupaten Gunungkidul dan Kota Yogyakarta. Untuk mendapatkan gambaran secara jelas terhadap para responden dalam penelitian ini, berikut ini 
akan dipaparkan usia responden, jenis kelamin responden, dan profesi atau pekerjaan dari para responden.

\section{a. Usia Responden}

Usia responden ini cukup penting karena menyangkut salah satu syarat yang harus dipenuhi seorang muzakki. Jumhur fuqaha menyatakan bahwa seseorang terkena kewajiban zakat jika yang bersangkutan telah dewasa. Dalam fikih klasik, kedewasaan seseorang dinilai dari tanda-tanda fisiknya, yaitu untuk laki-laki ditandai dengan mimpi basah dan untuk perempuan ditandai dengan menstruasi. Dalam era dewasa ini, ajaran seperti ini dirasakan kurang menjamin kepastian hukum, karena tanda-tanda fisik untuk setiap orang berbeda-beda. Untuk itu pada saat sekarang, kedewasaan seseorang diukur dari umur/usianya atau status pernikahannya. Berdasarkan ketentuan yang ada, seseorang dikatakan dewasa jika telah berusia sekurang-kurangnya 18 (delapan belas) tahun atau telah menikah ${ }^{9}$. Secara lengkap, usia para responden dalam penelitian ini dapat dilihat dalam tabel di bawah ini:

Tabel 1. Usia Responden

\begin{tabular}{cccc}
\hline No. & Usia (tahun) & Jumlah & Prosentase \\
\hline 1. & Di bawah 30 & 7 & 7 \\
2. & $30-40$ & 30 & 30 \\
3. & $41-50$ & 23 & 23 \\
4. & $51-60$ & 30 & 30 \\
5. & Di atas 60 & 10 & 10 \\
\hline & Jumlah & 100 & 100 \\
\hline
\end{tabular}

Sumber: Data Primer Tahun 2014.

Berdasarkan tabel di atas, para responden semuanya telah dewasa sehingga mereka telah memenuhi syarat sebagai muzakki, dalam arti mereka telah terkena kewajiban mengeluarkan zakat jika hartanya telah mencapai nisab dan haul. Dalam tabel di atas dapat dilihat bahwa usia responden antara 30 sampai 40 tahun serta antara 51 sampai 60 tahun menempati porsi tertinggi, yaitu $30 \%$, sementara usia di atas 60 tahun hanya $10 \%$ dan yang berusia di bawah 30 tahun menempati posisi terendah (7\%). Hal ini dapat dipahami, karena pada usia 30 sampai 40 tahun dan usia 51 sampai 60 tahun merupakan usia yang sangat produktif sehingga harta yang dikumpulkan juga mencapai titik optimal. Sementara di usia di bawah 30 tahun pada umumnya belum mencapai kemapanan ekonomi, sehingga penghasilan yang harus dikeluarkan zakatnya juga belum optimal. Adapun yang berusia di atas 60 tahun pada umumnya sudah kurang produktif lagi sehingga orang-orang yang berstatus muzakki pada usia ini juga tidak terlalu banyak.

\section{b. Jenis Kelamin Responden}

Jenis kelamin responden disini perlu dipaparkan karena terkait ketentuan dalam Islam bahwa dalam suatu keluarga yang mempunyai kewajiban mencari nafkah adalah laki-laki (suami), sementara perempuan tidak dibebani kewajiban demikian. Oleh karena itu, pada awalnya yang memiliki harta kekayaan adalah suami (laki-laki) sehingga kaum inilah yang memikul kewajiban zakat, bukan perempuan Walaupun demikian, dalam kenyataan di tengah masyarakat pihak yang membayar zakat tidak hanya laki-laki saja namun juga perempuan sebagaimana dapat dilihat dalam tabel di bawah ini;

Tabel 2. Jenis Kelamin Responden

\begin{tabular}{cccc}
\hline No. & Jenis Kelamin & Jumlah & Prosentase \\
\hline 1. & Laki-laki & 84 & 84 \\
2. & Perempuan & 16 & 16 \\
\hline & Jumlah & 100 & 100 \\
\hline
\end{tabular}

Sumber: Data Primer Tahun 2014. 
Berdasarkan tabel di atas, dapat dilihat bahwa sebagian besar (84\%) responden sebagai pembayar zakat (muzakki) adalah laki-laki, sementara responden perempuan hanya mencapai $16 \%$. Berdasarkan penelitian yang dilakukan, para responden perempuan ini juga mengeluarkan zakat sehingga berstatus sebagai muzakki (pembayar zakat) karena mereka juga punya pekerjaan dan penghasilan sendiri, terlepas dari penghasilan suaminya. Contohnya adalah di antara mereka ada yang menjadi Notaris/PPAT, pedagang, dan sebagainya.

\section{c. Pekerjaan Responden}

Pekerjaan dari para responden dalam penelitian ini cukup variatif. Pekerjaan atau profesi yang dijalani responden akan berkaitan erat dengan jenis zakat yang dikeluarkan. Dalam prakteknya seorang muzakki dapat mengeluarkan lebih dari satu jenis zakat dalam waktu yang bersamaan, beberapa di antaranya bahkan di luar profesi yang dijalaninya. Untuk lebih jelasnya, berikut ini akan dipaparkan berbagai profesi dari para responden dalam tabel sebagai berikut:

\section{Tabel 3. Pekerjaan Responden}

\begin{tabular}{clcc}
\hline No. & \multicolumn{1}{c}{ Pekerjaan } & Jumlah & Prosentase \\
\hline 1. & Pegawai Negeri Sipil & 26 & 26 \\
2. & TNI/POLRI & 2 & 2 \\
3. & Pegawai Swasta & 32 & 32 \\
4. & Wiraswasta & 16 & 16 \\
5. & Pedagang & 1 & 1 \\
6. & Petani & 3 & 3 \\
7. & Pensiunan & 11 & 11 \\
8. & Lain-lain & 9 & 9 \\
\hline & Jumlah & 100 & 100 \\
\hline
\end{tabular}

Sumber: Data Primer Tahun 2014.

Berdasarkan tabel di atas dapat dilihat bahwa sebagian besar (32\%) responden berprofesi sebagai pegawai swasta, di antaranya ada yang menjadi staf atau pegawai perusahaan swasta, sales, notaris/
PPAT, konsultan, dan sebagainya, selanjutnya responden yang berprofesi sebagai Pegawai Negeri Sipil ada 26\%, wiraswasta sebanyak $16 \%$ dan pensiunan sebanyak $11 \%$. Adapun responden yang berprofesi sebagai pedagang jumlahnya relatif kecil (hanya $1 \%$ ).

2. Kesadaran Hukum Umat Islam di Daerah Istimewa Yogyakarta untuk Membayar Zakat Melalui Badan Amil Zakat Nasional (BAZNAS) atau Lembaga Amil Zakat (LAZ)

Untuk mendapatkan gambaran tentang kesadaran hukum umat Islam di Daerah Istimewa Yogyakarta dalam pembayaran zakat melalui Badan Amil Zakat Nasional (BAZNAS) ataupun Lembaga Amil Zakat (LAZ), terlebih dahulu akan dipaparkan mengenai jenis-jenis zakat yang mereka keluarkan. Jenis-jenis zakat yang mereka keluarkan dapat dilihat dalam tabel di bawah ini:

Tabel 4. Jenis Zakat yang Dibayarkan Responden

\begin{tabular}{llcc}
\hline No. & \multicolumn{1}{c}{ Jenis Zakat } & Jumlah & Prosentase \\
\hline 1. & Zakat Profesi & 55 & 55 \\
2. & Zakat Perdagangan & 4 & 4 \\
3. & Zakat Emas/Perak & 1 & 1 \\
4. & Zakat Uang & 7 & 7 \\
& (Tabungan) & & \\
5. & Zakat Pertanian & 3 & 3 \\
6. & Zakat Peternakan & - & - \\
7. & Lain-lain & 19 & 19 \\
8. & Kombinasi beberapa & 11 & 11 \\
& jenis zakat & & \\
\hline \multicolumn{2}{l}{ Jumlah } \\
\hline
\end{tabular}

Sumber: Data Primer Tahun 2014.

Berdasarkan penelitian yang telah dilakukan sebagaimana terlihat dalam tabel di atas, beberapa responden (11 orang) menyatakan bahwa jenis zakat yang mereka keluarkan tidak hanya satu macam, melainkan ada beberapa macam. Perinciannya adalah sebagai berikut: beberapa responden (3 orang) menyatakan bahwa dalam periode yang sama dia mengeluarkan zakat profesi sekaligus zakat uang (tabungan) yang dimilikinya, 1 orang 
responden menyatakan mengeluarkan zakat profesi, zakat emas, dan zakat uang, 2 orang responden menyatakan mengeluarkan zakat profesi, zakat perdagangan, zakat emas, dan zakat uang, 1 orang responden lainnya menyatakan mengeluarkan zakat profesi dan zakat emas, 2 orang responden menyatakan mengeluarkan zakat profesi, zakat perdagangan, dan zakat uang, 1 orang responden menyatakan mengeluarkan zakat profesi dan zakat pertanian, serta 1 orang responden menyatakan mengeluarkan zakat uang dan zakat rikaz. Tabel di atas juga menunjukkan bahwa sebagian besar zakat yang dikeluarkan para responden adalah zakat profesi (55\%), disusul kemudian zakat lain-lain, misalnya zakat atas rezeki yang diterima secara tibatiba (19\%), kombinasi beberapa jenis zakat (11\%), zakat uang/tabungan (7\%), zakat perdagangan (4\%), zakat emas/perak (1\%), dan zakat pertanian (3\%).

Zakat profesi merupakan zakat yang dikeluarkan muzakki terkait dengan profesi yang dijalaninya. Pada masa Rasulullah, zakat profesi belum ada karena pada saat itu orang mencari penghasilan dengan pertanian, peternakan, dan perniagaan. Namun dalam perkembangannya, terdapat ijtihad dari para ulama tentang adanya zakat profesi. Dasar hukum adanya zakat profesi menurut Yusuf Qardawi adalah Firman Allah dalam Surat Al-Baqarah ayat 267 yang artinya "Hai orangorang yang beriman, nafkahkanlah (di jalan Allah) sebagian dari hasil usahamu yang baik-baik dan sebagian dari apa yang Kami keluarkan dari bumi untuk kamu". 'Umar bin Abd al-'Aziz adalah orang pertama yang mewajibkan zakat atas gaji, jasa honorarium, penghasilan dan berbagai jenis profesi.

Sebagaimana dipaparkan di atas, zakat profesi adalah zakat yang dikenakan kepada penghasilan para pekerja karena profesinya. Yang dimaksud dengan profesi adalah bidang pekerjaan yang dilandasi pendidikan keahlian (keterampilan, kejuruan, dan sebagainya) tertentu.
Sedangkan profesional adalah bersangkutan dengan profesi, memerlukan kepandaian khusus untuk menjalankannya, mengharuskan adanya pembayaran untuk melakukannya. ${ }^{10}$ Penulis lain menyatakan bahwa profesi adalah segala usaha yang halal yang mendatangkan hasil (uang) yang relatif banyak, dengan cara yang mudah, baik melalui suatu keahlian tertentu maupun tidak. ${ }^{11}$ Dengan demikian yang dimaksud zakat profesi adalah zakat yang dikeluarkan dari usaha yang halal, yang dapat mendatangkan hasil (uang) yang relatif banyak, dengan cara yang mudah dan melalui suatu keahlian tertentu. Dari definisi tersebut, dapat ditarik unsurunsur dari zakat hasil profesi, unsur tersebut yaitu jenis usahanya halal, menghasilkan uang relatif banyak, diperoleh dengan cara yang mudah, dan melalui suatu keahlian tertentu.

Berdasarkan kriteria tersebut, jenis-jenis usaha yang berhubungan dengan profesi seseorang seperti: (a) dapat berupa usaha fisik seperti pegawai dan artis; (b) usaha pikiran seperti konsultan, desainer dan dokter; (c) usaha kedudukan, seperti komisi dan tunjangan jabatan; (d) usaha modal, seperti investasi. Apabila ditinjau dari hasil usahanya, profesi itu bisa berupa: (a) Hasil yang teratur dan pasti, baik setiap bulan, minggu atau hari, seperti upah pekerja dan gaji pegawai; (b) Hasil yang tidak tetap dan tidak dapat diperkirakan secara pasti seperti kontraktor, pengacara, royalti pengarang, konsultan dan artis.

Yusuf al-Qardawi membagi dua kategori penghasilan profesi dan jasa yang terkena kewajiban zakat, yaitu kasb al-'amal (pekerjaan yang terikat pada lembaga atau perseorangan dengan mendapatkan gaji, upah, atau honorarium seperti karyawan, pegawai negeri sipil, tentara, dan sebagainya) dan al-mihan al-hurrah (pekerjaan yang tidak terikat pada orang lain, berkat kecekatan tangan atau otak, seperti pekerjaan seorang dokter, insinyur, advokat, seniman, tukang kayu, dan

\footnotetext{
10 Tim Penyusun Kamus Pusat Pembinaan dan Pengembangan Bahasa Departemen Pendidikan dan Kebudayaan, 1989, Kamus Besar Bahasa Indonesia, Cetakan ke-2, Balai Pustaka, Jakarta, hlm. 702.

11 Muhammad, 2002, Zakat Profesi (Wacana Pemikiran dalam Fiqih Kontemporer), Salemba Diniyah, Jakarta, hlm. 58.
} 
sebagainya). Jenis-jenis kekayaan seperti di atas menurut Yusuf al-Qardawi wajib dikenai zakat bila memenuhi nisab atau haul. ${ }^{12}$

Menurut Didin Hafidhudin, yang dimaksud zakat profesi adalah zakat yang dikenakan pada tiap pekerjaan atau keahlian profesional tertentu, baik yang dilakukan sendirian maupun yang dilakukan bersama dengan orang/lembaga lain, yang mendatangkan penghasilan (uang) yang memenuhi nisab (batas minimum untuk bisa berzakat). Contohnya adalah profesi dokter, konsultan, advokat, dosen, seniman perancang busana, dan sebagainya. Kewajiban zakat ini menurut beliau berdasarkan keumuman kandungan makna AlQur'an surat at-Taubah: 103, yang artinya "Ambillah olehmu harta-harta mereka, zakat [...]" dan surat al-Baqarah ayat 267 yang artinya "Wahai orangorang yang beriman, infakkanlah olehmu sekalian sebaik-baik hasil usahamu [...]". Disamping itu juga berdasarkan pada tujuan disyariatkannya zakat, yaitu untuk membersihkan dan mengembangkan harta, serta menolong para mustahik. ${ }^{13}$

Di kalangan ulama terjadi pro dan kontra menyangkut keberadaan zakat profesi ini. Sebagian ulama tidak mengakui keberadaan zakat profesi ini, sedangkan sebagian ulama lain menyetujui dan mendukung keberadaan zakat profesi ini. Ulama yang menolak adanya zakat profesi ini mendasarkan alasan bahwa zakat adalah termasuk kategori ibadah dan zakat profesi belum pernah terjadi pada masa Rasulullah SAW. Kaidah-kaidah ibadah bersifat tertutup, dalam arti tidak bisa dirubah atau ditambah. Dengan kata lain, kaidah asal ibadah itu adalah haram, artinya bahwa segala sesuatu yang menyangkut ibadah adalah haram dilakukan kecuali yang diperintahkan atau yang sudah disebutkan secara tegas dalam Al-Qur'an dan Sunnah Nabi. Menambah dan mengubah ketentuan di bidang ibadah termasuk kategori bid'ah dan bid'ah itu sesat. Dikarenakan dalam Al-Qur'an dan Sunnah Nabi, tidak ada satu ayat pun atau satu hadits pun yang secara tegas menyebutkan zakat profesi, maka mereka tidak mengakui adanya zakat profesi sebagaimana yang dikemukakan sebagian ulama lain. Menurut al-Jaziri dan Wahbah Al-Zuhayly, harta yang wajib dikenai zakat hanya ada lima macam, yaitu ternak, emas-perak, perdagangan, barang tambang-rikaz dan pertanian, tidak ada zakat di luar yang lima tersebut. ${ }^{14}$ Demikian juga Imam Syafi'i berpendapat bahwa harta penghasilan gaji dan profesi tidak wajib dizakati. ${ }^{15}$

Sebaliknya ulama lain yang menyetujui dan/atau mengakui zakat profesi ini mendasarkan pada dalil-dalil sebagai berikut: Pertama, berhujjah dengan apa yang disebut dengan mal almustafad. Mereka menyatakan bahwa terhadap mal al-mustafad harus dizakati sebesar $1 / 40$ begitu diterima. ${ }^{16}$ Mereka juga menyandarkan pada pendapat-pendapat para sahabat, semisal Ibnu 'Abbas, Ibnu Mas'ud, dan Mu'awiyyah; sebagian tabi'in misalnya al-Zuhri, al-Hasan, Makhul dan al-Bashriy'. Kedua, mereka juga menganalogikan (mengqiyaskan) zakat profesi dengan zakat uang dan harta, bahkan ada pula yang mengkaitkan dengan zakat hasil pertanian. Mereka beralasan, jika petani saja harus mengeluarkan zakat ketika panen, sedangkan hasilnya tidak seberapa dibandingkan profesi seorang dokter, insinyur, dan lain-lain, maka betapa tidak adilnya jika zakat profesi tidak disyari'atkan.

Adapun penentuan nisab, haul dan kadar zakat profesi terjadi perbedaan pendapat di kalangan ulama yang menyetujui zakat profesi. Pertama, Yusuf al-Qardhawi menganalogikan zakat profesi dengan zakat emas atau uang, yaitu 2,5\% dari sisa pendapatan bersih setahun, yakni pendapatan kotor dikurangi jumlah pengeluaran untuk kehidupan layak, seperti untuk makanan, pakaian, dan

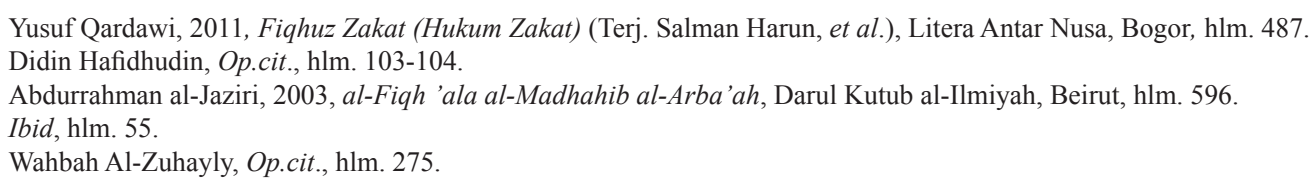


cicilan rumah ${ }^{17}$. Berdasarkan hal itu, maka sisa gaji dan pendapatan setahun wajib dikeluarkan zakatnya bila mencapai nisab uang, sedangkan gaji dan upah setahun yang tidak mencapai nisab uang (setelah biaya-biaya di atas dikeluarkan), misalnya gaji pekerja-pekerja dan pegawaipegawai kecil, tidak wajib zakat ${ }^{18}$. Sistem yang digunakan ini adalah dengan mengumpulkan gaji atau penghasilan yang diterima berkali-kali dalam waktu tertentu. Bila seseorang sudah mengeluarkan zakat gaji, penghasilan, atau sejenisnya pada waktu menerimanya, maka tidak wajib zakat lagi pada waktu masa tempo tahunnya sampai, sehingga tidak terjadi kewajiban mengeluarkan zakat dua kali pada satu kekayaan dalam satu tahun ${ }^{19}$. Kedua, Syeikh Muhammad al-Ghazali menganalogikan zakat profesi kepada zakat pertanian, sehingga berlaku nisab pertanian, tetapi tidak berlaku haul. Zakat profesi seperti zakat pertanian, dikeluarkan kapan saja seseorang memperoleh penghasilan. Jika seorang muslim mengeluarkan zakat atas pendapatan profesi atau pekerjaannya ketika dia menerimanya, maka dia tidak diwajibkan untuk mengeluarkan zakat lagi pada akhir tahun. Dengan begitu akan terjadi kesamaan antara pendapatan yang diperoleh melalui profesi dan penghasilan para petani. ${ }^{20}$ Penganalogian zakat gaji dengan zakat pertanian dilakukan karena ada kemiripan antara keduanya (al-syabah). Jika hasil panen pada setiap panen berdiri sendiri tidak terkait dengan hasil sebelumnya, demikian juga gaji dan upah yang diterima, tidak terkait antara penerimaan bulan kesatu, kedua, dan seterusnya. Hal ini berbeda dengan perdagangan yang selalu terkait antara bulan pertama, bulan kedua, dan seterusnya. Ketiga, Ulama lain meng-qiyaskan zakat profesi dengan zakat rikaz, sehingga kadarnya adalah $20 \%$.
Pendapat para ulama dalam menentukan nisab, haul dan kadar zakat profesi sebagaimana tersebut di atas dapat disederhanakan dalam bagan berikut ini: ${ }^{21}$

\begin{tabular}{|c|c|c|c|c|}
\hline & $\begin{array}{c}\text { Jenis } \\
\text { Barang }\end{array}$ & Nisab & Kadar & Waktu \\
\hline 1. & Profesi & $\begin{array}{l}\text { Diqiyaskan } \\
\text { dengan emas } \\
85 \text { gram }\end{array}$ & $2,5 \%$ & $\begin{array}{l}1 \text { tahun setelah } \\
\text { dikurangi } \\
\text { kebutuhan } \\
\text { pokok }\end{array}$ \\
\hline 2. & Profesi & $\begin{array}{l}\text { Diqiyaskan de- } \\
\text { ngan pertanian } \\
653 \mathrm{~kg} \text { padi }\end{array}$ & $5 \%$ & $\begin{array}{l}\text { Setiap panen } \\
\text { atau sebulan } \\
\text { sekali dari gaji }\end{array}$ \\
\hline 3. & Profesi & $\begin{array}{l}\text { Diqiyaskan } \\
\text { dengan zakat } \\
\text { rikaz }\end{array}$ & $20 \%$ & $\begin{array}{l}\text { Pada saat } \\
\text { menerimanya }\end{array}$ \\
\hline
\end{tabular}

Menurut Didin Hafidhuddin, setiap pekerjaan halal, seperti akuntan, dokter, notaris, dan sebagainya yang mendatangkan penghasilan, setelah dihitung selama satu tahun hasilnya mencapai nisab (senilai 85 gram emas) maka wajib dikeluarkan zakatnya sebesar 2,5\%. Ukuran baku nisab sebesar 85 gram emas sebagaimana disebutkan di atas, jika dikonversikan pada rupiah tentu sangat bergantung pada harga emas tersebut. Jika harga satu gram emas, misalnya Rp 200.000,00 maka batasan nisab adalah 85 x Rp 200.000,00, yaitu Rp 17.000.000,00. Jika pendapatan seseorang setelah dikurangi kebutuhan pokok selama satu tahun senilai dengannya atau lebih banyak, maka wajib mengeluarkan zakatnya sebesar 2,5\%.22 Wahbah al-Zuhayli menyatakan bahwa penghasilan yang diperoleh dari profesi seperti dokter, insinyur, advokat, wiraswasta, dan pegawai negeri wajib dikeluarkan zakatnya begitu gaji diterima, meskipun kepemilikannya belum sampai setahun. ${ }^{23}$ Dengan begitu, akan terjadi kesamaan antara pendapatan yang diperoleh melalui profesi-profesi tersebut dan penghasilan para petani

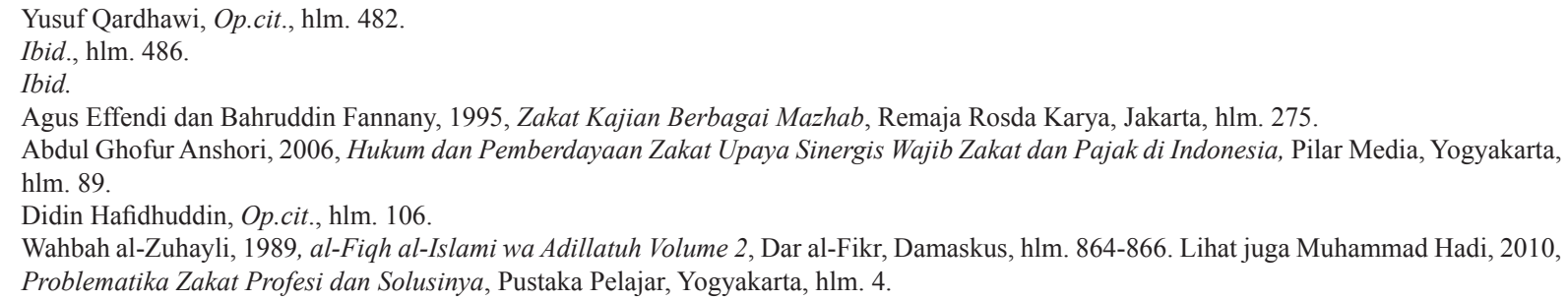


yang diharuskan mengeluarkan tanaman dan buahbuahan ketika mereka memetik dan memanen tanamannya.
Besarnya zakat yang dikeluarkan para responden dalam waktu satu tahun dapat dilihat dalam tabel di bawah ini:

Tabel 5. Besarnya Zakat yang Dibayarkan Responden per tahun (dalam Rupiah)

\begin{tabular}{lccc}
\hline No. & Besarnya Zakat & Jumlah & Prosentase \\
\hline 1. & Kurang dari $500.000,00$ & 47 & 47 \\
2. & $501.000,00-1.000 .000,00$ & 27 & 27 \\
3. & $1.001 .000,00-2.000 .000,00$ & 15 & 15 \\
4. & Di atas 2.000.000,00 & 11 & 11 \\
\hline & Jumlah & 100 & 100 \\
\hline
\end{tabular}

Sumber: Data Primer Tahun 2014.

Berdasarkan tabel di atas dapat dilihat bahwa sebagian besar responden (47\%) membayar zakat kurang dari Rp. 500.000,00 per tahun, sementara yang membayar zakat dengan jumlah antara $\mathrm{Rp}$. 501.000,00 sampai Rp. $1.000 .000,00$ ada 27\%, yang membayar zakat antara Rp. 1.001.000,00 sampai dengan Rp. 2.000.000,00 ada 15\%, dan yang membayar zakat dalam jumlah di atas $\mathrm{Rp}$. 2.000.000,00 per tahun jumlahnya relatif kecil, yaitu hanya $11 \%$.

Dengan melihat besarnya zakat yang dikeluarkan para responden sebagaimana terlihat dalam tabel di atas, dapat diperkirakan berapa besarnya harta kekayaan yang dimiliki para muzakki. Hal ini dikarenakan kadar zakat terhadap berbagai macam harta kekayaan telah ditentukan secara pasti dalam Islam. Yang dimaksud "kekayaan" (amwal) di sini adalah segala sesuatu yang dapat dimiliki dan disimpan untuk keperluan dan hal itu terutama menyangkut yang konkrit, dengan demikian pemilikan manfaat-manfaat tidak termasuk kekayaan ${ }^{24}$. Sebagai contoh, kadar zakat profesi menurut Keputusan Menteri Agama Nomor 52 Tahun 2014 adalah 2,5\% dari penghasilan yang dimiliki. Untuk zakat emas/perak dan uang atau tabungan adalah sebesar $2,5 \%$ dari emas atau perak atau uang yang dimilikinya. Dengan demikian, sesuai ketentuan di atas, jika seorang membayar zakat sebesar Rp 1.000.000,00 per tahun maka jumlah harta kekayaan yang dimilikinya dan kemudian dikeluarkan zakatnya adalah $\mathrm{Rp}$ 40.000.000,00. Harta yang dikeluarkan zakatnya tersebut merupakan harta kekayaan yang telah mencapai nishab dan haul-nya. Nishab artinya harta itu telah mencapai ukuran tertentu. Misalnya untuk hasil pertanian telah mencapai jumlah $653 \mathrm{~kg}$, untuk emas telah senilai 85 gram, untuk perdagangan telah mencapai nilai 85 gram emas, untuk uang atau tabungan telah mencapai jumlah senilai 85 gram emas, untuk penghasilan telah mencapai jumlah senilai 85 gram emas, untuk peternakan sapi telah mencapai 30 ekor, dan sebagainya. Adapun haul maksudnya bahwa harta tersebut telah dimiliki selama masa satu tahun sempurna (dua belas bulan), yang berturut-turut menurut hitungan tahun qamariyah, kecuali untuk harta yang berupa hasil tanaman dan barang temuan. Untuk hasil tanaman (pertanian) pengeluaran zakatnya tidak perlu menunggu waktu satu tahun, melainkan dikeluarkan pada saat memanennya (QS al-An'am ayat 141), demikian juga untuk harta karun (rikaz) atau barang temuan dikeluarkan zakatnya pada saat ditemukan.

Dalam menghitung besarnya zakat tersebut, sebagian muzakki ada yang menghitung sendiri sesuai dengan ketentuan hukum Islam, ada juga yang menghitung melalui perkiraan saja, namun tidak sedikit ada juga yang menyerahkan penghitungan zakat tersebut ke amil atau panitia zakat setempat. Hal ini dapat dilihat dalam tabel berikut:

24 Yusuf Qardhawi, Op.cit., hlm. 124. 
Tabel 6. Cara Penghitungan Zakat oleh Responden

\begin{tabular}{llcc}
\hline No. & \multicolumn{1}{c}{ Cara Penghitungan } & Jumlah & Prosentase \\
\hline 1. & Dihitung sendiri berdasarkan Hukum Islam & 63 & 63 \\
2. & Dihitung sendiri berdasarkan perkiraan & 18 & 18 \\
3. & Diserahkan amil/panitia zakat untuk menghitungnya & 14 & 14 \\
4. & Tidak menjawab & 5 & 5 \\
\hline \multicolumn{2}{c}{ Jumlah } & 100 & 100 \\
\hline
\end{tabular}

Sumber: Data Primer Tahun 2015.

Berdasarkan tabel di atas dapat dilihat bahwa sebagian besar responden (63\%) menghitung sendiri besarnya zakat yang harus mereka keluarkan sesuai dengan ketentuan hukum Islam. Hal ini menunjukkan bahwa sebagian besar responden memahami betul tentang kewajiban zakat dan besarnya zakat yang harus mereka keluarkan. Sementara itu $18 \%$ responden lainnya menghitung besarnya zakat yang harus ia keluarkan berdasarkan perkiraan saja, artinya ia tidak menghitung secara persis berapa harta kekayaan yang ia miliki dan berapa besarnya zakat yang harus dikeluarkannya. Mereka hanya memperkirakan secara global saja besarnya zakat yang harus dibayarkannya. Adapun 14\% responden berikutnya menyerahkan penghitungan zakat yang harus ia keluarkan kepada 'amil atau panitia zakat di sekitar tempat tinggalnya. Hal ini dikarenakan walaupun mereka tahu tentang kewajiban zakat dan sadar untuk mengeluarkannya, namun mereka tidak paham berapa besarnya zakat yang harus dikeluarkannya. Oleh karena itu, dari pada keliru dalam menghitung besarnya zakat yang harus ia keluarkan, maka mereka menyerahkan urusan itu kepada 'amil atau panitia zakat. Mereka hanya menyatakan kepada 'amil atau panitia zakat,berapa besarnya harta kekayaan yang ia miliki dan selanjutnya 'amil atau panitia zakat yang akan menghitung besarnya zakat dari yang bersangkutan.

Waktu pembayaran zakat yang dilakukan oleh para responden, cukup variatif. Ada yang membayarkannya secara rutin setiap bulan atau setiap tahun, namun tidak sedikit pula yang membayarkan zakatnya tidak rutin, dalam arti bersifat spontanitas. Misalnya ketika mendapat rezeki yang cukup banyak maka ia secara langsung mengeluarkan zakatnya. Waktu atau periode pembayaran zakat tersebut dapat dilihat dalam tabel di bawah ini.

Tabel 7. Periode Pembayaran Zakat oleh Responden

\begin{tabular}{cccc}
\hline No. & $\begin{array}{c}\text { Periode } \\
\text { Pembayaran }\end{array}$ & Jumlah & Prosentase \\
\hline 1. & Setiap bulan & 26 & 26 \\
2. & Setiap tahun & 43 & 43 \\
3. & Tidak tertentu & 31 & 31 \\
\hline & Jumlah & 100 & 100 \\
\hline
\end{tabular}

Sumber: Data Primer Tahun 2014.

Berdasarkan tabel di atas dapat dilihat bahwa sebagian besar (43\%) responden membayarkan zakatnya setiap tahun, dan yang membayarkan zakatnya setiap bulan ada $26 \%$. Adapun responden yang membayarkan zakatnya tidak secara rutin untuk waktu tertentu ada 31\%. Untuk kelompok yang terakhir ini contohnya adalah responden yang berprofesi sebagai penyedia jasa jual beli tanah, ketika tanahnya laku dan ia mendapatkan keuntungan atau komisi tertentu maka ia kemudian mengeluarkan zakatnya.

Dalam ketentuan Islam, waktu pengeluaran zakat tergantung pada jenis harta yang ia miliki. Pada umumnya suatu harta wajib dikeluarkan zakatnya setelah dimiliki selama satu tahun secara terus menerus, artinya telah memenuhi haul-nya. Namun ada juga beberapa jenis harta kekayaan yang harus dikeluarkan zakatnya tanpa harus menunggu waktu satu tahun, seperti untuk hasil tanaman, diantaranya padi, yang harus dikeluarkan sehabis memanennya, dan untuk barang temuan harus dikeluarkan seketika itu juga. Untuk zakat profesi sendiri, 
di kalangan fuqaha terdapat berbagai pendapat. Sebagian fuqaha membolehkan pembayaran zakat dilakukan setiap bulan untuk memudahkan dan meringankan muzakki, sementara para fuqaha lainnya berpendapat bahwa pembayaran zakat profesi dilakukan setelah satu tahun. Artinya bahwa penghasilan dari yang bersangkutan dikalkulasi dulu selama satu tahun, kemudian dikurangi untuk mencukupi kebutuhan pokok bagi dirinya dan keluarganya, barulah sisanya dikeluarkan zakatnya jika telah mencapai nishab.

Para responden menyadari bahwa zakat merupakan salah satu kewajiban fundamental yang harus mereka tunaikan sebagai seorang muslim. Namun demikian tidak semua responden memahami bahwa pembayaran zakat sesuai ajaran Islam harus dilakukan melalui amil zakat. Tidak sedikit di antara mereka membayarkan zakatnya secara langsung kepada mustahik. Hal tersebut dapat dilihat dalam tabel di bawah ini:

\section{Tabel 8. Cara Pembayaran Zakat oleh Responden}

\begin{tabular}{clcc}
\hline No. & Cara Pembayaran & Jumlah & Prosentase \\
\hline 1. & $\begin{array}{l}\text { Diserahkan langsung } \\
\text { ke mustahik }\end{array}$ & 49 & 49 \\
2. $\begin{array}{l}\text { Disalurkan melalui } \\
\text { amil zakat dari takmir } \\
\text { masjid setempat }\end{array}$ & 28 & 28 \\
3. $\begin{array}{l}\text { Disalurkan melalui } \\
\text { Badan Amil Zakat } \\
\text { Nasional (BAZNAS) }\end{array}$ & 6 & 6 \\
4. $\begin{array}{l}\text { Disalurkan melalui } \\
\text { Lembaga Amil Zakat } \\
\text { (LAZ) }\end{array}$ & 10 & 10 \\
5ain-lain & \multicolumn{1}{c}{ Jumlah } & 100 & 7 \\
\hline
\end{tabular}

Sumber: Data Primer Tahun 2014.

Berdasarkan tabel di atas dapat dilihat bahwa sebagian besar (49\%) responden mengeluarkan zakatnya dengan cara menyerahkan langsung kepada mustahik (orang-orang yang berhak menerima zakat) seperti fakir miskin atau anak-anak terlantar yang ada di sekitar tempat tinggal muzakki. Mereka membayarkan zakatnya tanpa melalui perantaraan amil. Sementara itu responden yang membayarkan zakatnya melalui amil zakat yang dibentuk oleh takmir masjid setempat dimana muzakki bertempat tinggal ada 28\%. Adapun responden yang membayar zakat melalui Badan Amil Zakat Nasional (BAZNAS) yang dibentuk Pemerintah hanya ada 6\%. Responden yang membayarkan zakatnya melalui Badan Amil Zakat Nasional (BAZNAS) semuanya berprofesi sebagai Pegawai Negeri Sipil. Mereka mengeluarkan zakatnya secara rutin dengan cara potong gaji oleh bendahara dimana ia bekerja dan selanjutnya oleh bendahara zakat tersebut disetorkan ke BAZNAS di wilayah kerjanya. Responden yang membayarkan zakatnya melalui Lembaga Amil Zakat (LAZ) yang dibentuk oleh organisasi non-pemerintah, seperti Dompet Dhuafa, LAZIS Muhammadiyah dan sebagainya ada $10 \%$. Sementara itu ada $7 \%$ responden yang membayarkan zakatnya melalui lembaga tertentu di luar BAZNAS atau LAZ, seperti ke Pondok Pesantren, Panti Asuhan, ataupun Yayasan Majelis Tafsir Al-Qur'an (MTA).

Dengan melihat data di atas, dapat dilihat bahwa sebagian besar responden yang merupakan para muzakki membayarkan zakatnya tidak melalui Badan Amil Zakat Nasional (BAZNAS) ataupun Lembaga Amil Zakat (LAZ) sebagaimana dikehendaki Undang-undang Pengelolaan Zakat. Mereka justru membayarkan zakatnya dengan cara diserahkan secara langsung ke para mustahik. Ada beberapa alasan mengapa mereka berbuat demikian. Hal tersebut akan dibahas pada sub bab berikutnya. Kenyataan ini menunjukkan bahwa kesadaran hukum umat Islam di Daerah Istimewa Yogyakarta untuk membayarkan zakatnya melalui Badan Amil Zakat Nasional (BAZNAS) ataupun Lembaga Amil Zakat (LAZ) masih relatif rendah (hanya 16\%).

3. Faktor yang Mempengaruhi Kesadaran Hukum Umat Islam di Daerah Istimewa Yogyakarta untuk Membayar Zakat Melalui Badan Amil Zakat Nasional (BAZNAS) atau Lembaga Amil Zakat (LAZ)

Sebagaimana dipaparkan pada pembahasan di atas, sebagian besar muzakki di Daerah Istimewa 
Yogyakarta membayarkan zakatnya secara langsung kepada mustahik, dan hanya sebagian kecil saja yang membayarkan zakatnya melalui Badan Amil Zakat Nasional (BAZNAS) ataupun Lembaga Amil Zakat
(LAZ) sebagaimana dikehendaki Undang-undang Pengelolaan Zakat. Ada beberapa faktor atau alasan yang melatarbelakangi kondisi demikian. Hal tersebut dapat dilihat dalam tabel di bawah ini:

Tabel 9.

Alasan Muzakki Membayar Zakat Melalui BAZNAS/LAZ dan Tidak Melalui BAZNAS/LAZ

\begin{tabular}{|c|c|c|c|c|}
\hline \multirow[b]{2}{*}{ No. } & \multicolumn{2}{|r|}{ Alasan } & \multirow[b]{2}{*}{ Jumlah } & \multirow[b]{2}{*}{ Prosentase } \\
\hline & Melalui BAZNAS/LAZ & Tidak Melalui BAZNAS/LAZ & & \\
\hline 1. & Lebih praktis dan mudah & - & 9 & 9 \\
\hline 2. & $\begin{array}{l}\text { Zakat akan disalurkan secara } \\
\text { tepat kepada yang berhak }\end{array}$ & - & 6 & 6 \\
\hline 3. & Lain-lain & - & 1 & 1 \\
\hline 4. & - & Tidak mengetahui lembaga tersebut & 5 & 5 \\
\hline 5. & - & $\begin{array}{l}\text { Mengetahui lembaga tersebut tetapi } \\
\text { sulit menjangkaunya }\end{array}$ & 11 & 11 \\
\hline 6. & - & $\begin{array}{l}\text { Mengetahui lembaga tersebut tetapi } \\
\text { kurang percaya terhadap kinerjanya }\end{array}$ & 9 & 9 \\
\hline 7. & - & Lain-lain & 59 & 59 \\
\hline \multicolumn{3}{|c|}{ Jumlah } & 100 & 100 \\
\hline
\end{tabular}

Sumber: Data Primer Tahun 2014.

Berdasarkan tabel di atas, dapat dilihat bahwa muzakki yang membayarkan zakatnya melalui BAZNAS atau LAZ karena alasan lebih praktis dan mudah ada sembilan orang atau $9 \%$. Alasan ini dikemukakan oleh muzakki yang zakatnya dibayarkan dengan cara potong gaji setiap bulan ataupun dengan cara layanan jemput zakat dari LAZ tertentu, sehingga ia tidak perlu repot-repot membawa dan menyetorkan zakatnya kepada yang berhak. Responden lainnya yang membayarkan zakatnya melalui BAZNAS/LAZ beralasan bahwa zakat yang ia bayarkan ke BAZNAS atau LAZ akan benar-benar disalurkan kepada mereka yang berhak, karena kedua lembaga tersebut adalah lembaga yang profesional dan amanah. Hal dikemukakan oleh enam responden atau $6 \%$.

Adapun muzakki yang tidak membayar zakat melalui BAZNAS atau LAZ beralasan karena mereka tidak mengetahui keberadaan lembaga tersebut (5\%), atau mengetahui adanya lembaga tersebut namun sulit untuk menjangkaunya (11\%). Alasan yang disebutkan terakhir ini dikemukakan oleh para responden yang tinggal di pelosok dimana di situ tidak ada kantor perwakilan dari BAZNAS ataupun LAZ. Selanjutnya 9\% responden lainnya yang tidak membayarkan zakatnya melalui BAZNAS/LAZ beralasan mengetahui adanya organisasi BAZNAS ataupun LAZ namun tidak percaya terhadap kinerja kedua lembaga tersebut. Mereka tidak yakin bahwa zakat yang telah ia bayarkan akan benar-benar sampai kepada yang berhak. Adapun sebagian besar (59\%) responden yang tidak membayarkan zakatnya melalui BAZNAS ataupun LAZ melainkan disalurkan secara langsung ke mustahik memiliki alasan sendiri, yaitu sebagai berikut: Pertama, agar zakatnya dapat sampai kepada pihak yang ia inginkan, seperti fakir miskin yang tinggal di sekitar tempat tinggalnya; Kedua, lebih praktis dan mudah, karena pihak mustahik (penerima zakat) ada di sekitar tempat tinggalnya yang setiap hari ia jumpai; Ketiga, untuk menyambung silaturahmi, hal ini khusus terhadap zakat yang disalurkan muzakki kepada kerabatnya atau tetangganya sendiri; Keempat, agar zakat bisa 
langsung dimanfaatkan oleh mereka yang berhak, tanpa harus melalui pihak ketiga ('amil); Kelima, merasa lebih afdhol jika zakatnya langsung diserahkan ke mustahik karena ia bisa bertatap muka langsung kepada penerimanya; Keenam, jumlah zakat yang disalurkan tidak seberapa, sehingga ia merasa "malu" jika zakatnya diserahkan melalui BAZNAS ataupun LAZ; Ketujuh, merasa yakin bahwa zakatnya sampai kepada pihak yang benarbenar berhak menerimanya karena ia lebih tahu keadaan penerima zakat yang ia berikan.

\section{Efektivitas Ketentuan Undang-Undang} Pengelolaan Zakat Menyangkut Pengumpulan Zakat melalui Badan Amil Zakat Nasional (BAZNAS) atau Lembaga Amil Zakat (LAZ)

Sebuah undang-undang dibuat dengan harapan ketentuan dalam undang-undang tersebut ditaati atau dilaksanakan oleh masyarakat. Dengan kata lain, undang-undang yang dibuat tersebut dapat berlaku efektif. Menurut Soerjono Soekanto, efektivitas suatu undang-undang dipengaruhi oleh beberapa faktor, yaitu faktor undang-undangnya sendiri, faktor penegak hukum atau pelaksana hukum, faktor fasilitas, faktor kesadaran hukum masyarakat, dan faktor budaya hukum. Hal ini senada dengan Teori Sistem Hukum (Legal System) yang dikemukakan L. Friedman, yang menyatakan bahwa keberlakuan hukum dipengaruhi tiga faktor, yaitu substansi hukum (legal substance), struktur hukum (legal structure), dan budaya hukum (legal culture). Kesadaran hukum masyarakat atau budaya hukum yang akan melahirkan kepatuhan hukum tidak muncul begitu saja, melainkan melalui beberapa tahap. Tahap-tahap tersebut adalah pengetahuan hukum, pemahaman hukum, sikap hukum, dan perilaku hukum. Semakin tinggi kualitas dalam tahap-tahap tersebut akan melahirkan kesadaran hukum yang tinggi dan pada akhirnya akan memunculkan kepatuhan hukum yang tinggi pula.

Sesuai dengan ketentuan Undang-undang Pengelolaan Zakat, pembayaran zakat oleh muzakki (wajib zakat) diharapkan dilakukan melalui Badan Amil Zakat Nasional (BAZNAS) atau Lembaga Amil Zakat (LAZ). Berdasarkan penelitian yang telah dilakukan, para responden menyatakan bahwa penunaian zakat yang mereka lakukan semata-mata dilandasi niat untuk melaksanakan perintah Allah. Untuk masalah pembayaran zakat yang seyogyanya dilakukan melalui BAZNAS/LAZ sebagaimana diatur dalam Undang-undang Pengelolaan Zakat, yaitu Undang-undang Nomor 23 Tahun 2011, tidak semua responden mengetahui dan memahaminya. Hal itu bisa dilihat dalam tabel berikut ini:

Tabel 10. Pemahaman Responden terhadap Undang-undang Pengelolaan Zakat (UUPZ)

\begin{tabular}{llcc}
\hline No. & \multicolumn{1}{c}{ Pemahaman } & Jumlah & Prosentase \\
\hline 1. & Tidak mengetahui dan tidak memahami UUPZ & 55 & 55 \\
2. & Mengetahui UUPZ tetapi tidak memahami isinya & 31 & 31 \\
3. & Mengetahui dan memahami isi UUPZ & 14 & 14 \\
\hline & Jumlah & 100 & 100 \\
\hline
\end{tabular}

Sumber: Data Primer Tahun 2014.

Berdasarkan tabel di atas dapat dilihat bahwa sebagian besar responden (55\%) walaupun selama ini telah membayar zakat namun tidak mengetahui dan tidak memahami adanya Undang-undang Pengelolaan Zakat (UUPZ), sedangkan 31\% responden lainnya mengetahui adanya Undang- undang Pengelolaan Zakat (UUPZ) tersebut namun tidak memahami isinya karena belum pernah membacanya. Hanya ada $14 \%$ responden saja yang mengetahui dan memahami isi Undang-undang Pengelolaan Zakat (UUPZ).

Salah satu hal pokok yang diatur dalam 
Undang-undang Pengelolaan Zakat (UUPZ) adalah bahwa pengelolaan zakat (mulai dari pengumpulan, pendistribusian, sampai pendistribusiannya) dilakukan oleh dua macam organisasi pengelola zakat yaitu Badan Amil Zakat Nasional (BAZNAS) dan Lembaga Amil Zakat. Dengan pengelolaan zakat secara baik oleh lembaga-lembaga tersebut, tujuan pengelolaan zakat sebagaimana digariskan undangundang tersebut, yakni a. meningkatkan efektivitas dan efisiensi pelayanan dan pengelolaan zakat, dan b. meningkatkan manfaat zakat untuk mewujudkan kesejahteraan masyarakat dan penanggulangan kemiskinan, ${ }^{25}$ dapat tercapai.

Adanya kenyataan bahwa sebagian besar responden tidak mengetahui dan tidak memahami isi Undang-undang Pengelolaan Zakat (UUPZ), memiliki korelasi dengan cara pembayaran zakat yang dilakukannya. Sebagian besar dari mereka tidak membayarkan zakatnya melalui Badan Amil Zakat Nasional (BAZNAS) atau Lembaga Amil Zakat (LAZ), melainkan disalurkan langsung ke mustahik. Walaupun hal ini secara syar' $i$ tidak bisa disalahkan, namun makna zakat sebagai instrumen untuk meningkatkan kesejahteraan dan menanggulangi kemiskinan kurang bisa diwujudkan secara optimal. Dengan demikian, ketentuan Undang-undang Pengelolaan Zakat (UUPZ) yang menyangkut pengumpulan zakat melalui Badan Amil Zakat Nasional (BAZNAS) atau Lembaga Amil Zakat (LAZ) dalam kenyataannya kurang efektif. Salah satu faktor penyebabnya adalah karena kurangnya pemahaman masyarakat terhadap substansi undang-undang tersebut yang mana hal itu berdampak pada lemahnya kesadaran hukum. Lemahnya kesadaran hukum berakibat pada rendahnya kepatuhan hukum masyarakat terhadap undang-undang yang bersangkutan.

\section{Penutup}

Kesadaran hukum umat Islam di Daerah Istimewa Yogyakarta untuk membayar zakat melalui Badan Amil Zakat Nasional (BAZNAS) atau Lembaga Amil Zakat (LAZ) masih relatif rendah. Sebagian besar umat Islam masih menyalurkan zakatnya secara langsung kepada para mustahik. Faktor yang mempengaruhi rendahnya kesadaran hukum umat Islam di Daerah Istimewa Yogyakarta untuk membayar zakat melalui Badan Amil Zakat Nasional (BAZNAS) atau Lembaga Amil Zakat (LAZ) adalah kurangnya pengetahuan dan pemahaman umat Islam terhadap isi Undangundang Pengelolaan Zakat (Undang-undang Nomor 23 Tahun 2011). Ketentuan Undang-undang Pengelolaan Zakat belum efektif dalam meningkatkan pengumpulan zakat melalui BAZNAS atau LAZ.

Dalam rangka meningkatkan kesadaran hukum umat Islam di Daerah Istimewa Yogyakarta dalam membayar zakat melalui Badan Amil Zakat Nasional (BAZNAS) atau Lembaga Amil Zakat (LAZ), maka perlu dilakukan sosialisasi Undangundang Pengelolaan Zakat kepada umat Islam, baik melalui media masa, selebaran, maupun dengan tatap muka secara langsung yang melibatkan tokohtokoh Islam, seperti ustadz, kyai, dan sebagainya, dan juga pemberian keteladanan oleh tokoh-tokoh umat Islam mengenai hal tersebut. Dengan langkah seperti ini, umat Islam akan mengetahui dan memahami isi undang-undang tersebut, yang salah satunya menyangkut ketentuan pembayaran zakat melalui Badan Amil Zakat Nasional (BAZNAS) atau Lembaga Amil Zakat (LAZ). Dengan mengetahui dan memahami isi undang-undang tersebut diharapkan akan melahirkan sikap dan perilaku umat Islam untuk membayar zakat melalui Badan Amil Zakat Nasional (BAZNAS) atau Lembaga Amil Zakat (LAZ).

25 Pasal 3 Undang-Undang Nomor 23 Tahun 2011 tentang Pengelolaan Zakat (Lembaran Negara Republik Indonesia Tahun 2011 Nomor 115, Tambahan Lembaran Negara Republik Indonesia 5255). 


\section{DAFTAR PUSTAKA}

\section{A. Buku}

A. Hadi, Muhammad, 2010, Problematika Zakat Profesi dan Solusinya, Pustaka Pelajar, Yogyakarta.

al-Jaziri, Abdurrahman, 2003, Al-Fiqh 'Ala AlMadzahib Al-Arba'ah, Darul Kutub AlIlmiyah, Beirut.

Anshori, Abdul Ghofur, 2006, Hukum dan Pemberdayaan Zakat Upaya Sinergis Wajib Zakat dan Pajak di Indonesia, Pilar Media, Yogyakarta.

Effendi, Agus dan Bahruddin Fannany, 1995, Zakat Kajian Berbagai Mazhab, Remaja Rosda Karya, Jakarta.

Friedman, Lawrence M., 2012, The Legal System (A Social Science Perspective), terj. M. Khozim, Nusa Media, Bandung.

Hafidhuddin, Didin, 2004, Islam Aplikatif, Gema Insani Press, Jakarta.

Hafidhuddin, Didin, 2004, Zakat dalam Perekonomian Modern, Gema Insani Press, Jakarta.

Muhammad, 2002, Zakat Profesi (Wacana Pemikiran dalam Fiqih Kontemporer),
Salemba Diniyah, Jakarta.

Qardawi, Yusuf, 2011, Fiqhuz Zakat (Hukum Zakat), (Terj. Salman Harun, et al.), Litera Antar Nusa, Bogor.

Tim Penyusun Kamus Pusat Pembinaan dan Pengembangan Bahasa Departemen Pendidikan dan Kebudayaan, 1989, Kamus Besar Bahasa Indonesia, Cetakan ke-2, Balai Pustaka, Jakarta.

\section{B. Artikel Koran}

Harian Kedaulatan Rakyat, 4 April 2013.

\section{Peraturan Perundang-undangan}

Undang-Undang Nomor 23 Tahun 2011 tentang Pengelolaan Zakat (Lembaran Negara Republik Indonesia Tahun 2011 Nomor 115, Tambahan Lembaran Negara Republik Indonesia Nomor 5255).

\section{Internet}

Monzer Kahf, "Zakah”, http://www.monzerkahf. com, diakses 25 Januari 2012. 